\title{
Money Demand Function: \\ A Not-So-Fond Farewell in the Light of Financial Development
}

\author{
Masudul Hasan Adil ${ }^{1+}$, Neeraj Hatekar ${ }^{2}$, Sana Fatima ${ }^{3}$, Ibrahim Nurudeen ${ }^{4}$, and Shan Mohammad ${ }^{5}$ \\ ${ }^{1}$ Indian Institute of Technology-Palakkad, India \\ ${ }^{2}$ University of Mumbai, India \\ ${ }^{3}$ GLA University, India \\ ${ }^{4}$ Shehu Shagari College of Education, Nigeria \\ ${ }^{5}$ Aligarh Muslim University, India
}

\begin{abstract}
This study investigates the stability issues of real money balances considering financial development. We estimate real narrow (M1) and broad (M3) money demand in India during the post-financial reform, from 1996:Q2 to 2016:Q3. To check the short- and long-run relationships, this study uses the autoregressive distributed lag model of cointegration and other various time series techniques. After incorporating financial development into money demand, we determined short- and long-run relationships and a well-defined open-economy stable money demand specification (M1 and M3) in India. Having established money demand function, the policymaker and central bankers can use monetary aggregates as an indicator or information variable to predict output gaps and inflationary expectations under the inflation-targeting framework.
\end{abstract}

Keywords: inflation-targeting, money demand, financial development, bound testing, cointegration, impulse response

JEL Classifications: E00, E4, E41, E52

Received 24 April 2021, Revised 14 November 2021, Accepted 17 November 2021

\section{Introduction}

Monetary policy formulation is an integral part of the macroeconomic policy framework, which generally helps sustain overall macroeconomic stability, particularly price stability. The

\footnotetext{
+Corresponding Author: Masudul Hasan Adil

Institute Postdoctoral Fellow, Indian Institute of Technology Palakkad, Palakkad-678623, Kerala, India.

Email: adilmasood.alig@gmail.com

Co-Author: Neeraj Hatekar

Professor of Econometrics, Mumbai School of Economics and Public Policy, University of Mumbai, Mumbai-400098, Maharashtra, India. Email: neeraj.hatekar@gmail.com

Co-Author: Sana Fatima

Assistant Professor, GLA University, Mathura-281406, Uttar Pradesh, India. Email: sana.fatima@gla.ac.in

Co-Author: Ibrahim Nurudeen

Assistant Professor, Shehu Shagari College of Education, Sokoto, Nigeria. Email: nibrahim44@gmail.com

Co-Author: Shan Mohammad

Research Scholar, Department of Economics, Aligarh Muslim University, Aligarh-202002, Uttar Pradesh, India.

Email: shaanecohit@gmail.com
} 
money demand function (hereinafter MDF) is a cornerstone of monetary policy because it helps assess the monetary sector's impact on the real sector. However, the following issues are related to MDF: (i) the empirical definition of money, (ii) choice of appropriate scale and opportunity cost variables, (iii) role of adjustment and expected lags, (iv) estimation of functional forms, and (v) temporal stability (Laidler, 1969). MDF has been widely researched, and its most commonly researched issue is stability. A stable MDF means that, as observed in the real world, money holdings can be explained by functional relationships, including a relatively small number of arguments, to conventionally acceptable levels of statistical significance (Laidler, 1982). The existence of a stable MDF can help policymakers formulate macro-econometric models.

In earlier studies, although the stability of MDF featured prominently, it has become secondary since the emergence of financial development, financial deregulation, and financial liberalization1) or innovation 2 ) in the 1970s and 1980s. These financial changes affect money demand stability; in turn, the money has started losing its focus from monetary policy. Therefore, in monetary policy formulation, the role of monetary aggregates targeting (based on stable MDF) has declined, whereas inflation-targeting (based on interest rate targeting) has been focused across the globe. In this backdrop, the present study examines the impact of financial development on money demand stability and enquires whether MDF has some information useful for inflation-targeting.

The policymakers and economists have been doubtful regarding the role of money in monetary policy under inflation-targeting. In this framework, a structured MDF is required for tracking the interest rate and stock of money, thus resulting in effective implementation of monetary policy (Singh and Pandey, 2009). Therefore, it has been a conflicting issue among researchers to come up with a stable MDF, which can guide policymakers to take effective steps in setting up monetary policy.

The unstable MDF has divided the strand of literature into two different schools of thought: New-Keynesian and New-monetarists. The New-Keynesian economists 3 ) favor the disappearance of the liquidity-money (LM) curve or money or MDF from the monetary policy framework. Woodford (2000) argued that money is irrelevant for monetary policy formulation. He stated that, "even if the demand for base money for use in facilitating transactions is largely or even completely eliminated, monetary policy should continue to be effective" (p. 229). It is so because central banks can focus on macroeconomic stabilization by governing "a short-term nominal interest rate, and this would continue to be possible, in particular, through the use of a 'channel' system for the implementation of policy, like those currently used in Canada, Australia, and

1) Financial liberalization is broadly defined to encompass financial innovations and institutional/regulatory changes (James, 2005).

2) Financial innovation can be categorized in the form of a new product, or a new process for supplying an already existing product, or be in terms of market arrangements (Lewis \& Mizen, 2000).

3 ) For an extensive view on the role of money from the New-Keynesian perspective, see, inter alia, Romer (2000), Woodford (2000), and Svensson (2008). 
New Zealand" (Woodford, 2000, p. 229). Likewise, Svensson (2008) mentioned that "monetary aggregates matter little, or even not at all, for monetary policy" (p. 4).

Nevertheless, new monetarists have been uncomfortable with the increasing role of interest rate and the diminishing role of money in monetary policy. The new-monetarist economists 4 ) favor money, and they maintain that the role of MDF from a monetary policy cannot be totally neglected. King (2001) and Nelson (2003) made caution for ignoring the significance of money, while maintaining price stability, in monetary policy operation. Similarly, Thornton (2014) proposed another viewpoint: "Money is essential for monetary policy because it is essential for controlling the price level, and the monetary authority's ability to control interest rates is greatly exaggerated" (p. 202). Meanwhile, Bordo and Jonung (2003) argued that the economists and central bankers envisage money supply as proportional to the rate of inflation; therefore, future forecast of an upsurge in inflation is mostly bound to look back into money demand issues. As evidenced from the recent incidence, after the 2007 financial crisis, the role of MDF in monetary policy is hotly debated to design and conduct a rule-based monetary policy for price stability in advanced and emerging market economies.

A consequence of the dispute over money has been the resurgence of research interest in money demand for the conduct of monetary policy targeting price stability (Hossain, 2012). In the essence of these dynamics of monetary policy thinking, this study reexamines whether an economically meaningful and stable MDF exists in India after factoring financial development into account. Earlier studies have found a stable MDF after incorporating financial innovation as an explanatory variable (see, inter alia, Arrau et al., 1995; Dekle and Pradhan, 1999; James, 2005; Adil et al., 2020a). In the phase of financial liberalization of the Indian economy, re-investigating stable MDF under the current monetary policy framework is inevitable due to numerous reasons. First, the 1996:Q2-2016:Q3 period that is selected for the current study is significant, because it considers the post-1990s financial reform of the Indian economy. These financial reforms have changed the money holding behavior of economic agents; in turn, it must have affected the stability and made the estimation of MDF difficult. Second, since the inception of inflation-targeting in India, after the Report of the Expert Committee to Revise and Strengthen the Monetary Policy Framework in 2014, no studies have investigated MDF after taking financial development, to the best of authors' knowledge. Furthermore, an alternative monetary strategy based on the New-Keynesian dynamic stochastic general equilibrium framework has been developed, which focuses on money growth as unimportant. However, new-monetarists have raised their concern about excluding money from monetary policy. Therefore, studying MDF would be a great deal to provide some policy insights for inflationtargeting countries like India. Third, after the emergence of financial development, there exists mixed evidence on money demand stability in India (see, inter alia, Aggarwal, 2016; Adil et al., 2020c).

4) For an extensive view on the role of money from a new-monetarist perspective, see, inter alia, Barnett (1997), King (2001), Friedman (2003), Nelson (2003), Christiano et al., (2007), and Thornton (2014). 
In this backdrop, MDF must be re-investigated afresh after considering financial development.

The remainder of the study is structured as follows. Section 2 briefly presents the literature survey on the stability issues of MDF. Section 3 provides a theoretical underpinning for money demand estimation. Section 4 gives the variables' description and dataset extraction. Section 5 proposes a research methodology under study. Section 6 discusses the empirical results. Finally, Section 7 presents the summary and concluding remarks.

\section{Literature Review}

Theoretically, among different approaches to MDF, stable MDF is a key to determining the impact of monetary policy on real economic activities. To this end, a strand of empirical literature has been conducted to find the determinants of a stable MDF. Several studies, particularly during and after the 1970s, have shown instability in the MDF, in the case of advanced economies (in the US context, see Goldfeld et al., 1976, and in Latin American countries, see Darrat, 1986). However, the introduction of the cointegration approach has boosted the need for establishing a stable MDF. In the case of the US, Miller (1991) stated that monetary policy could be effectively implemented using M2 monetary aggregate. Likewise, Hoffman and Rasche (1989) and McNown and Wallace (1992) supported the stability of M2 in the US. Meanwhile, Adam (1991) and Melnick (1990) concluded that the currency devaluation leads to instability in the MDF in the UK and Argentina, respectively. Bahmani-Oskooee and Shabsigh (1996) noted that the exchange rate plays an important role in making MDF stable in Japan. For Korea, Bahmani-Oskooee and Rhee (1994) determined a long-run equilibrium relationship between M2 and its covariates. In the context of China, Hafer and Kutan (1994) stated that M2 can be used to find a stable MDF. In a nutshell, studies posited that the stability of MDF is a prerequisite to conduct an effective monetary policy. Furthermore, in Table 1, we summarize the relevant literature on stability issues to provide a relative viewpoint for readers.

In the empirical literature survey, mixed results have been found on stability issues in advanced and emerging economies, in general, and in India, in particular. In the case of unstable MDF, the rationale is the emergence of financial development or financial liberalization. It is not exaggerated to say that the financial structure is an important pillar for the overall development of an economy. Therefore, consideration of financial development in a policy formulation is a prerequisite for the effective implementation of monetary policy. In earlier studies, due importance has not been given to financial innovation as a critical determinant for stable MDF. Broadly speaking, the work of Arrau and Gregorio (1993), Arrau et al. (1995), Siklos (1993), and Dekle and Pradhan (1999) drew the attention of researchers toward financial innovation as an important determinant. Moreover, Gurley and Shah (1955) highlighted the financial aspects of economic development; by then, 
researchers have started to rethink money demand stability from a different perspective. In conclusion, financial development is inevitable for stable MDF.

Table 1. Empirical Studies on Money Demand Function and its Stability

\begin{tabular}{|c|c|c|c|}
\hline Studies & Countries and sample covered & Methodology & Conclusion \\
\hline Baba et al. (1992) & US, $1960-1988$ & $\mathrm{ECM}$ & Stable M1 money demand \\
\hline $\begin{array}{l}\text { Arrau and Gregorio } \\
(1993)\end{array}$ & $\begin{array}{l}\text { Chile, 1975:Q1-1989:Q4 and } \\
\text { Mexico, 1980:Q1-1989:Q3 }\end{array}$ & $\begin{array}{l}\text { Unit root test and } \\
\text { cointegration test }\end{array}$ & Unstable M1 money demand \\
\hline Arrau et al. (1995) & $\begin{array}{l}\text { Ten emerging countries, } \\
\text { Used different rime period }\end{array}$ & $\begin{array}{l}\text { Unit root tests, } \\
\text { EG cointegration and OLS }\end{array}$ & $\begin{array}{c}\text { Stable M1 and } \\
\text { M2 monetary aggregate }\end{array}$ \\
\hline $\begin{array}{l}\text { Dekle and Pradhan } \\
\text { (1999) }\end{array}$ & $\begin{array}{l}\text { ASEAN-4: Indonesia, Malaysia, } \\
\text { Singapore and Thailand }\end{array}$ & Johansen cointegration test & $\begin{array}{c}\text { Stable M1 and } \\
\text { M3 money demand }\end{array}$ \\
\hline $\begin{array}{l}\text { Funke and Thornton } \\
\text { (1999) }\end{array}$ & Italy, $1861-1980$ & $\begin{array}{l}\text { Unit root test, } \\
\text { cointegration test, and ECM }\end{array}$ & Stable M3 money demand \\
\hline $\begin{array}{l}\text { Bahmani-Oskooee } \\
\text { and } \mathrm{Ng}(2002)\end{array}$ & Hong Kong, 1985:Q1-1999:Q4 & $\begin{array}{l}\text { ARDL cointegration test } \\
\text { and ECM }\end{array}$ & Stable M2 money demand \\
\hline Payne (2003) & Croatia, 1994:M6-2002:M8 & $\begin{array}{l}\text { Unit root tests, ECM, and ARDL } \\
\text { cointegration test }\end{array}$ & Stable M1 money demand \\
\hline $\begin{array}{l}\text { Ramachandran } \\
(2004)\end{array}$ & India, $1951-52$ to $2000-01$ & GH cointegration and ECM & Stable M3 money demand \\
\hline $\begin{array}{l}\text { Bahmani-Oskooee } \\
\text { and Rehman (2005) }\end{array}$ & $\begin{array}{l}\text { Seven Asian countries, } \\
\text { 1973-2000 Quarterly data }\end{array}$ & $\begin{array}{l}\text { ARDL cointegration test } \\
\text { and ECM }\end{array}$ & $\begin{array}{c}\text { Stable M1 and } \\
\text { M2 monetary aggregates }\end{array}$ \\
\hline James (2005) & Indonesia, 1983:Q1-2000:Q4 & $\begin{array}{l}\text { Unit root test and } \\
\text { ARDL cointegration test }\end{array}$ & Stable M2 money demand \\
\hline $\begin{array}{l}\text { Bahmani-Oskooee } \\
\text { and Wang (2007) }\end{array}$ & China, 1983:Q1-2002:Q4 & $\begin{array}{c}\text { Unit root test, ARDL } \\
\text { cointegration test, and ECM }\end{array}$ & $\begin{array}{c}\text { Stable M1 but } \\
\text { M2 money demand is doubtful }\end{array}$ \\
\hline Ball (2012) & US, 1959-1993 & $\begin{array}{l}\text { Partial adjustment model } \\
\text { and cointegration test }\end{array}$ & $\begin{array}{l}\text { Stable short-and long-run } \\
\text { M1 money demand }\end{array}$ \\
\hline Hossain (2012) & Australia, 1970-2009 & $\begin{array}{l}\text { Unit root test, ARDL } \\
\text { cointegration, and ECM }\end{array}$ & $\begin{array}{c}\text { Stable M1 but not } \\
\text { M3 monetary aggregate }\end{array}$ \\
\hline $\begin{array}{l}\text { Kumar and Weber } \\
(2013)\end{array}$ & $\begin{array}{l}\text { Australia and New Zealand, } \\
1960-2009\end{array}$ & $\begin{array}{l}\text { Unit root test with and without } \\
\text { break, GH cointegration test }\end{array}$ & $\begin{array}{l}\text { Unstable M1 for 1984-1998, } \\
\text { thereafter stable money demand }\end{array}$ \\
\hline $\begin{array}{l}\text { Bahmani-Oskooee } \\
\text { et al. (2015) }\end{array}$ & UK, 1997:Q1-2013:Q3 & $\begin{array}{l}\text { Unit root test and } \\
\text { ARDL cointegration test }\end{array}$ & Stable M2 monetary aggregate \\
\hline $\begin{array}{l}\text { Bahmani-Oskooee } \\
\text { and Bahmani (2015) }\end{array}$ & Iran, 1947:M1-2003:M12 & $\begin{array}{l}\text { ARDL and Nonlinear } \\
\text { ARDL cointegration test }\end{array}$ & Stable M2 money demand \\
\hline Aggarwal (2016) & India, 1996-2013 & $\begin{array}{l}\text { Unit root test with and } \\
\text { without break, DOLS }\end{array}$ & No long-run relationship for M1 \\
\hline $\begin{array}{l}\text { Bahmani-Oskooee } \\
\text { and Baek (2017) }\end{array}$ & Korea, 1973:Q3-2014:Q3 & $\begin{array}{l}\text { Unit root test, GRACH, and } \\
\text { ARDL cointegration test }\end{array}$ & Stable M2 money demand \\
\hline $\begin{array}{l}\text { Haider et al. } \\
(2017)\end{array}$ & India, 2004:M4-2015:M11 & $\begin{array}{l}\text { Unit root test and Nonlinear } \\
\text { ARDL cointegration tests }\end{array}$ & $\begin{array}{c}\text { Stable M1 and } \\
\text { M3 money demand }\end{array}$ \\
\hline $\begin{array}{l}\text { Adil et al. } \\
(2020, a)\end{array}$ & India, 1996:Q2-2016:Q3 & $\begin{array}{l}\text { Unit root tests and } \\
\text { ARDL cointegration tests }\end{array}$ & $\begin{array}{c}\text { Stable M1 and } \\
\text { M3 money demand }\end{array}$ \\
\hline
\end{tabular}

Notes. M1, M2, and M3 denote real narrow money, and broad money The ECM, OLS, DOLS, ARDL, GH, and GARCH stands for error-correction mechanism, ordinary least squares, dynamic OLS, autoregressive distributed lag, GregoryHansen, and generalized autoregressive conditional heteroscedasticity, respectively.

Source: Authors' compilation 
In the case of India, several studies have estimated MDF and checked its stability. However, to the best of our knowledge, none of the studies have estimated MDF after taking financial development. Therefore, this study fills this gap and contributes to the existing literature on several other counts, as already discussed in Section 1.

\section{Theoretical Underpinnings}

The stability of MDF is a combination of a limited set of arguments, that is, whether it is capable of predicting demand for money with a high degree of accuracy (Friedman, 1956). The MDF includes scale variable (i.e., real income) and opportunity cost variable (i.e., nominal interest rate) as principal arguments. The literature on MDF for open economies suggests that the exchange rate and foreign interest rate of domestic currency were used to reflect the wealth-holders' portfolioadjustment responses to changes in returns on foreign and domestic assets (Bahmani-Oskooee, 2001). In this study, the econometric specification of MDF is based on a log-linearized version of a conventional long-run theoretical MDF (Goldfeld, 1989). Furthermore, following the argument made by Mundell (1963) for the exchange rate and Mwanzia et al. (2017) for stock prices, the study incorporates these two variables in MDF.

Besides, the study turns to the contribution of the current work and incorporates a measure of "financial development," another significant determinant of money demand. The financial development accounts for the plausible breakdown in the real demand for money and facilitates resolving the stability issues of MDF. In the late 1980s and 1990s, the breakdown has started in the Indian economy due to the emergence of major economic reforms in terms of financial development and liberalization. As Ramachandran (2004) rightly noted, those reforms dismantled the administered interest rates, the unification of dual exchange rates by introducing a market-based exchange rate system, and a phased move toward convertibility on the current account. In the literature, several proxies have been used to capture financial development, ranging from interest rates to monetary aggregates, the ratio of the size of the banking system, and gross domestic product (GDP) (Hassan et al., 2011), viz., monetization ratio, turnover ratio, claims, and currency ratios. However, this study uses the most significant proxy, in context with money supply, liquidity, and credit behavior in the economy. That is, credit to the private non-financial sector from all sectors at market valuea percentage of GDP. A high ratio of domestic credit to GDP implies a higher level of domestic investment and higher development of the financial system. It will further increase the linkages between financial and real sectors of the economy as it translates financial lending into productive investment. Therefore, the financial system that allocates more credit to private sectors more likely affect the behavior of economic agents in terms of cash balance management practices, facilitating transactions, and mobilizing savings. Consequently, money demand stability might 
be affected. Against this backdrop, using credit to the private non-financial sector as a proxy for financial development may help retrieve the stability of money demand.

The log-linear form of MDF, alternately, with real narrow and broad money, may be postulated as follows:

$$
L n R_{j} M_{t}=\beta_{0}+\beta_{1} L n Y_{t}+\beta_{2} r_{j t}+\beta_{3} L n E R_{t}+\beta_{4} L n S P_{t}+\beta_{5} F D_{t}
$$

where $\operatorname{Ln} R_{j} M_{t}$ is the natural $\log$ of real money balances (narrow, $j=\mathrm{N}$ and broad, $j=\mathrm{B}$ ), $\operatorname{Ln} Y$ is a $\log$ of GDP at constant prices, and $r$ is the interest rate (short-term, $j=$ TB-91 and long-term interest rate, $j=\mathrm{G}-\mathrm{Sec} 10$ ). Moreover, $L n E R$ is the $\log$ of the exchange rate, $L n S P$ is a $\log$ of stock prices, $F D$ stands for financial development, and $t$ is a time subscript. Finally, $\beta_{n}(\mathrm{n}=$ $0,1,2,3,4,5)$ are structural parameters to be estimated using time series data at a quarterly frequency. The model specified in Equation (1) is a long-run equilibrium relationship. As Laidler (1993) argued, "the long-run MDF [which] is important for the rule-based monetary policy rather than the short-run function." Hence, in the current work, the values of the following parameters and the temporal stability of each are needed: the elasticity of demand for money to real income, domestic interest rate, exchange rate, stock prices, and FD. Hence, a quarterly dataset is expected to unlock whether the long-run relationship of MDF in India is capable enough to predict inflation gaps or output gaps in the current inflation-targeting framework.

In Equation (1), the sign of the coefficients can be revealed through empirical testing. However, a priori, scale, and opportunity cost variables are supposed to be positively and negatively related to real money balances. Moreover, the exchange rate and stock prices may move either in a positive or negative direction, depending on the strength of wealth and currency substitution effect (for a detailed discussion, see Adil et al., 2020b). Lastly, the financial innovation and development may be positive or negative in sign with real money balances, depending on either institutional and technological advancement (negative sign) or increasing monetization and financial deepening (a positive sign) (Dekle and Pradhan, 1999).

\section{Dataset and Variables' Description}

\section{A. The dataset}

The dataset is taken from the Handbook of Statistics on Indian Economy (HSIE), BSE Historical Indices, Bank for International Settlement (BIS), and EPW Research Foundation. The following data are extracted: real narrow money (M1) and real broad money (M3), which are considered a proxy for money demand; real gross domestic product (GDP) used for scale variable; 91 days 
Treasury Bill (TB-91) — short-term interest rate — used as an opportunity cost for M1; ten-year government securities (G-Sec10) - long-term interest rate - used as an opportunity cost for M35); nominal effective exchange rate (NEER = Trade weighted average of 36 currency basket per Rupee) used for the exchange rate; Sensex used for stock prices (SP); and credit to the private nonfinancial sector from all sectors at market value - a percentage of GDP — used as a proxy for financial development (FD). The G-Sec10 and TB-91 are extracted from the $E P W$ research foundation. Meanwhile, the Sensex dataset and FD data are taken from BSE Historical indices and BIS, respectively. The rest of the variables' dataset is extracted from the HSIE. Importantly, all series, except for GDP and FD, are extracted monthly, and then, monthly series are converted into quarterly frequency. Ultimately, this left us with 82 observations from 1996:Q2 to 2016:Q3. Except for TB-91, G-Sec10, and FD, all variables are converted into a natural logarithmic form to interpret the coefficients into elasticity form and compress the scale. Furthermore, we use the seasonally adjusted data by deploying the X-13 ARIMA technique.

\section{B. Results of descriptive statistics}

Table 2 summarizes descriptive statistics of variables under study. LnM1 depicts a positive mean value (i.e., 4.707), with a range consisting of 3.905 and 5.537 as the minimum and maximum values, respectively, from 1996:Q2 to 2016:Q3. Similarly, the mean value for all variables is positive. In general, skewness and kurtosis are measurements of the normality of the series distribution. In particular, skewness assesses the extent of symmetricity of the variable's distribution, whereas kurtosis depicts peakedness or flatness of variable distribution. Each variable shows normality because none of them are greater than +1 or -1 , which means the variables' distribution has 0

Table 2. Descriptive Statistics

\begin{tabular}{lccccccccc}
\hline Variables & Min & Max & 1.Qu. & 3.Qu. & Mean & Median & Stdev & Skew & Kurt \\
\hline LnM1 & 3.905 & 5.537 & 4.254 & 5.125 & 4.707 & 4.791 & 0.472 & -0.130 & -1.375 \\
LnM3 & 4.975 & 7.022 & 5.531 & 6.531 & 6.022 & 6.014 & 0.595 & -0.084 & -1.266 \\
LnY & 8.519 & 9.827 & 8.788 & 9.500 & 9.149 & 9.149 & 0.396 & 0.036 & -1.375 \\
LnER & 3.548 & 4.212 & 3.775 & 3.903 & 3.856 & 3.825 & 0.162 & 0.518 & -0.175 \\
LnSP & 7.970 & 10.269 & 8.271 & 9.817 & 9.097 & 9.211 & 0.791 & -0.047 & -1.649 \\
TB-91 & 3.275 & 11.789 & 5.670 & 8.364 & 6.996 & 7.081 & 1.768 & -0.064 & -0.337 \\
G-Sec10 & 5.128 & 13.968 & 7.496 & 9.608 & 8.690 & 8.034 & 2.172 & 0.829 & -0.188 \\
FD & 27.200 & 62.000 & 32.750 & 58.875 & 46.130 & 49.800 & 12.928 & -0.178 & -1.691 \\
\hline
\end{tabular}

Notes. Min stands for minimum, Max for maximum, Qu1 is the first quartile, Qu3 is the third quartile, Stdev is the standard deviation, Skew stands for skewness, and Kurt depicts kurtosis.

Source: Authors' Calculation

5) Different interest rates are chosen depending upon the aggregation of M1 and M3 components. 
skewness. However, a negative excess kurtosis (i.e., platykurtic distribution) is reflected in all variables except $\operatorname{LnER}, T B-91$, and G-Sec10, which have 0 kurtosis (i.e., mesokurtic). All in all, variables under study follow a normal distribution. Likewise, other statistics can also be analyzed. Lastly, the plot of the respective variables is depicted in Figure 1. The trend and their fluctuations in the variables are self-explanatory.

Figure 1. Underlying time series variables for the period 1996:Q2-2016:Q3

Graph of SP

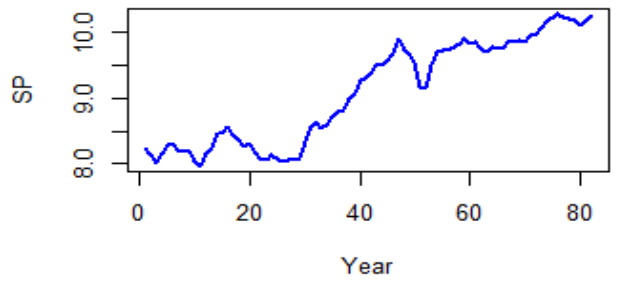

Graph of G-Sec10

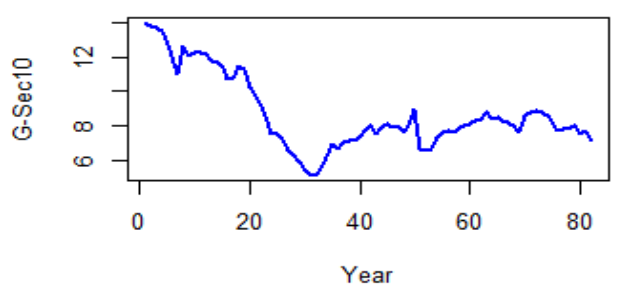

Graph of M1

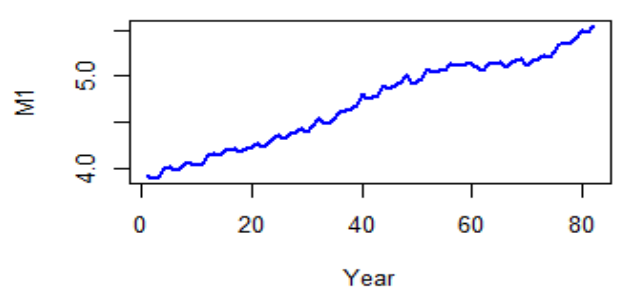

Graph of RGDP

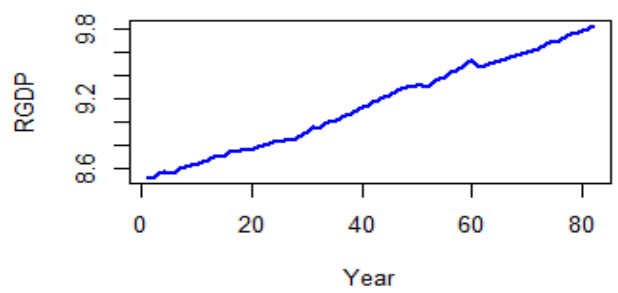

Graph of TB-91

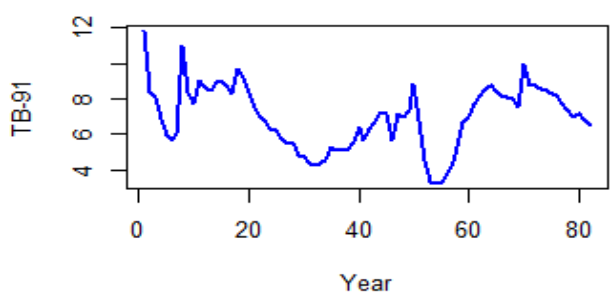

Graph of FD

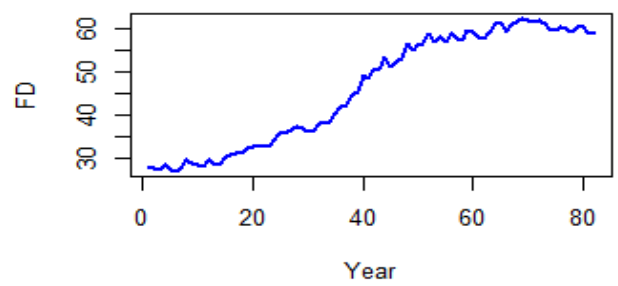

Graph of M3

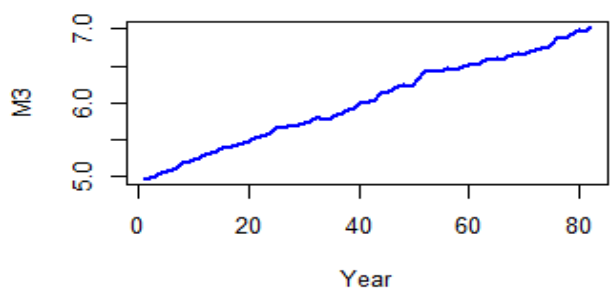

Graph of ER

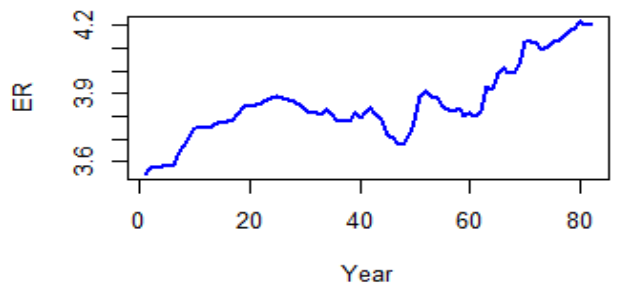

Source: Authors' Calculation 


\section{Research Methodology}

\section{A. Stationarity test}

To test the direction of causality and avoid spurious regression, this study employed a threestage procedure. In the first stage, the order of integration of the variables is identified using Augmented Dickey-Fuller (ADF) and Phillips-Perron (PP) unit root tests by Dickey and Fuller (1981) and Phillips and Perron (1988), respectively. To apply the ARDL model, a few conditions must be met, such as variables should be following I(0), I(1) process purely, or mutually cointegrated, but none of the variables should be I(2).

\section{B. Autoregressive distributed lag approach to cointegration}

We check the long-run equilibrium relationship between real money balances and their covariates in the second stage. Accordingly, the study applies the bounds testing or Pesaran et al.'s (2001) autoregressive distributed lag (ARDL) approach to cointegration, which has been extensively used due to its advantages. For instance, it can be used irrespective of the order of integration of variables, that is, I(0), I(1), or a combination of both. The ARDL approach integrates the short-run impact of the variables with the long-run equilibrium with the help of an error-correction term (ECT), making it easier to assess the short-and long-run relationship among variables. Unlike traditional cointegration tests, different lags can be calculated for variables of interest used in the model (Pesaran et al. 2001), which enhances its flexibility. Most cointegration techniques are prone to sample size; therefore, the ARDL method aims to provide accuracy of findings for limited sample sizes (Pesaran et al. 2001). In the context of our postulated MDF, the ARDL model can be specified as follows:

$$
\begin{aligned}
\Delta L n R_{j} M_{t}= & C_{01}+\sum_{i=1}^{n 1} \delta_{1 i} \Delta L n R_{j} M_{t-i}+\sum_{i=0}^{n 2} \delta_{2 i} \Delta L n Y_{t-i}+\sum_{i=0}^{n 3} \delta_{3 i} \Delta r_{j_{t-i}} \\
& +\sum_{i=0}^{n 4} \delta_{4 i} \Delta L n E R_{t-i}+\sum_{i=0}^{n 5} \delta_{5 i} \Delta L n S P_{t-i}+\sum_{i=0}^{n 6} \delta_{6 i} \Delta F D_{t-i}+\gamma_{1} L n R_{j} M_{t-1} \\
& +\gamma_{2} \operatorname{Ln} Y_{t-1}+\gamma_{3} \gamma_{j_{t-1}}+\gamma_{4} L n E R_{t-1}+\gamma_{5} L n S P_{t-1}+\gamma_{6} F D_{t-1}+\mu_{t}
\end{aligned}
$$

where variables are already defined in Equation (1). $\Delta$ is the first difference operator, $C_{01}$ is the intercept, subscript $t$ shows time, $\delta_{1 i}, \delta_{2 i}, \delta_{3 i}, \delta_{4 i}, \delta_{5 i}$, and $\delta_{6 i}$ are the coefficients of the shortrun dynamics, $\gamma_{1}, \gamma_{2}, \gamma_{3}, \gamma_{4}, \gamma_{5}$, and $\gamma_{6}$ represent coefficients of the long-run relationship of variables under study, and $\mu_{t}$ represents an error term, which follows the IID process. To confirm the long-run relationship, we calculate the F-statistic. If the calculated F-statistic is larger than the upper 
bound critical value, the null hypothesis of no cointegration (i.e., $\mathrm{H}_{0}: \gamma_{1}=\gamma_{2}=\gamma_{3}=\gamma_{4}=\gamma_{5}=$ $\left.\gamma_{6}=0\right)$ is rejected, and the alternative hypothesis of cointegration $\left(\mathrm{H}_{\mathrm{a}}: \gamma_{1} \neq \gamma_{2} \neq \gamma_{3} \neq\right.$ $\gamma_{4} \neq \gamma_{5} \neq \gamma_{6} \neq 0$ ) is accepted. Conversely, if it is less than the lower bound critical value, then we fail to reject the null hypothesis of no cointegration. However, if the F-statistic falls within the lower and upper bound critical values, then the opinion on cointegration is indeterminate.

Once the cointegrating relationship among variables is established using the bound test, the final step is to estimate the long-run and short-run error-correction mechanisms (ECM). They are stated as follows:

$$
\begin{aligned}
& L n R_{j} M_{t}=C_{02}+\sum_{i=1}^{n 1} \delta_{1 i} L n R_{j} M_{t-i}+\sum_{i=0}^{n 2} \delta_{2 i} \operatorname{Ln} Y_{t-i}+\sum_{i=0}^{n 3} \delta_{3 i} r_{j_{t-i}}+\sum_{i=0}^{n 4} \delta_{4 i} \operatorname{Ln} E R_{t-i} \\
& +\sum_{i=0}^{n 5} \delta_{5 i} L n S P_{t-i}+\sum_{i=0}^{n 6} \delta_{6 i} F D_{t-i}+\mu_{t} \\
& \Delta L n R_{j} M_{t}=C_{03}+\sum_{i=1}^{n 1} \varnothing_{1 i} \Delta L n R_{j} M_{t-i}+\sum_{i=0}^{n 2} \varnothing_{2 i} \Delta L n Y_{t-i}+\sum_{i=0}^{n 3} \varnothing_{3 i} \Delta r_{j_{t-i}} \\
& +\sum_{i=0}^{n 4} \varnothing_{4 i} \Delta L n E R_{t-i}+\sum_{i=0}^{n 5} \varnothing_{5 i} \Delta L n S P_{t-i}+\sum_{i=0}^{n 6} \varnothing_{6 i} \Delta F D_{t-i} \\
& +\psi E C T_{(t-1)}+\mu_{t}
\end{aligned}
$$

In Equation (3), $\delta_{1 i}, \delta_{2 i}, \delta_{3 i}, \delta_{4 i}, \delta_{5 i}$ and $\delta_{6 i}$ are the long-run coefficient and in Equation (4), $\varnothing_{1 i}, \varnothing_{2 i}, \varnothing_{3 i}, \varnothing_{4 i}, \varnothing_{5 i}$ and $\varnothing_{6 i}$ are coefficients of short-run dynamics. The ECT is derived from the long-run relationship, and $\psi$ is the coefficient of ECT, which shows the speed of adjustment to long-run equilibrium following a shock to the system.

The ARDL model can only be considered valid if the model follows some diagnostic and stability tests. The diagnostic tests check for serial correlation, heteroscedasticity, the functional form of the model, and normality of residual term. Meanwhile, the stability tests are conducted using the cumulative sum of recursive residuals (CUSUM) and the cumulative sum of squares (CUSUMQ) of recursive residuals.

\section{Granger causality based on vector error-correction model}

The third stage comprises constructing standard Granger-type causality tests enlarged with a lagged ECT, where the variables under study are cointegrated. The multivariate $p$ th order vector error-correction model (VECM) for the MDF is represented as follows:

$$
(1-L)\left(Y_{i t}\right)=\left(\alpha_{i}\right)+\sum_{i=1}^{p}(1-L)\left(\partial_{i j, l}\right)\left(Y_{t-i}\right)+\left(\phi_{i}\right)\left(E C T_{t-1}\right)+\left(\epsilon_{i t}\right)
$$


where variables are previously defined, $(1-L)$ is the difference operator, $E C T_{t-1}$ is the oneperiod lagged ECT extracted from the long-run cointegrating vector, and $\epsilon_{i t}$ is the column vector of serially independent random errors with mean zero and finite covariance matrix. $Y_{i t}$ is the column vector of all variables: $\left(Y_{i t}\right)=\left(L n R_{i} M_{t}, r_{i t}, L n E R_{t}, L n S P_{t}, F D_{t}\right)$. Moreover, $\alpha_{i}$ represents the column vector of intercept, $\partial_{i j, l}$ represents a symmetric matrix of short-run coefficients, and $\phi_{i}$ is supposed to be negatively significant, which reinforces the long-run equilibrium relationship among variables. In every case, the response variable is regressed against past values of itself and other explanatory variables. The optimal lag length $p$ is based on the Akaike information criterion (AIC). Further, the existence of long-run Granger causality is tested using a $t$-test for the statistical significance of $\phi_{i}$, whereas the statistical significance $\partial_{i j, l}$ is tested by the Wald's test $\chi^{2}$-statistic for the combined significance of lagged values of variable exhibiting short-run dynamics or causal relationship. Therefore, the ECT allows us to test additional sources of Granger causality. Furthermore, the impulse response function (IRFs) and variance decompositions (VDs) are applied to check the robustness of the causality analysis.

\section{Parameter stability}

Parameter tests are important because only stable parameters will lead to better policy prescriptions. Over time, the estimated parameter of time series may vary; hence, unstable parameters can result in model misspecification. In turn, the model will provide biased results. We use Pesaran and Pesaran's (1997) test to check parameter stability. The short-run dynamics are essential to test the long-run coefficient stability of the model under study (Pesaran and Pesaran, 1997). Hence, they suggested estimating ECM as represented in Equation (4), provided that the dependent variable has a long-run relationship. After estimating the model, Pesaran and Pesaran (1997) suggested applying CUSUM and CUSUMQ tests developed by Brown et al. (1975) to assess parameter constancy for examining the structural stability of the error-correction models. CUSUM helps detect systematic changes in the regression coefficients, whereas the CUSUMQ test is useful in the sense where departure from the constancy of the regression coefficients is abrupt and sudden. The model is estimated using ordinary least squares (OLS), and the residuals are subject to the CUSUM and CUSUMQ testing.

\section{E. Generalized impulse response function and variance decomposition}

Impulse response analysis is a useful tool for examining economic variables' relationship. Specifically, IRF identifies the responsiveness of the dependent variable in the vector autoregression (VAR) framework, when a shock is put to the error term. It is also considered an alternative to obtaining information among variables in the VD analysis. A shock to the $i$-th variable directly affects 
the $i$-th variable and is also transmitted to other endogenous variables through the dynamic (lag) structure of the VECM. Thus, IRF traces the effect of a one-time shock to an innovation on the endogenous variables' current and future values.

In particular, IRF traces the effects of a shock to one endogenous variable on the other variables in the cointegrated VAR framework. Meanwhile, VD separates the variation in an endogenous variable into the component shocks to the cointegrated VAR. As Narayan and Smyth (2004) noted, "the recognition of plausible Granger exogeneity or endogeneity of the dependent variable in the sample period is restricted to essentially within-sample tests, but as far as degree of exogeneity of the variables beyond the sample period is concerned, Granger causality is unable to deduce" ( $p$. 32). Consequently, the study considers the VD, which provides information about the relative importance of each random innovation in affecting the variables in cointegrated VAR (in the system). Thus, VD measures the percentage of a variable's forecast error variance that occurs because of a shock from other variables in the system. Sims (1980) noted, "if own innovations will be explaining all of the variables forecast error variance, then that variable will be called as truly exogenous with respect to the other variables in the system." Lastly, to gauge the model adequacy, study employs a series of diagnostic testing.

\section{Empirical Analysis}

\section{A. Unit root tests result}

To determine the stochastic properties, the present study checks the integrating property of the series by employing unit root tests. Table 3 reports the ADF and PP results. Both results depict similar findings. All variables, except TB-91 and G-Sec10, are non-stationary.6) However, after the first difference, the non-stationary series becomes stationary. Thus, the study contains a mixture of both $\mathrm{I}(0)$ and $\mathrm{I}(1)$; in turn, the application of ARDL is justified. Some variables follow the $\mathrm{I}(0)$ process, which shows the individual stability, whereas the rest follow the $\mathrm{I}(1)$ process, which is unstable individually. Having determined the stochastic properties, we now turn to assess the combined stability of the series, that is, whether the series are cointegrated in the long run. This study uses the ARDL approach of cointegration.

6) The empirical testing of the variables by ADF and PP tests suggests that almost variables have singular integration; hence, the study supports the growing recognition that the majority of the macroeconomic series are I(1) (Nelson and Plosser, 1982). 
Table 3. Unit Root Test Results (ADF and PP)

\begin{tabular}{|c|c|c|c|c|}
\hline \multirow{2}{*}{ Variables } & \multicolumn{2}{|c|}{ ADF Statistic [LL] } & \multicolumn{2}{|c|}{ PP Statistic $\{B W\}$} \\
\hline & Level & First Difference & Level & First Difference \\
\hline \multirow[t]{2}{*}{ Ln MI } & $0.216[4]$ & $-2.878[3]$ & $0.114\{19\}$ & $-20.154\{60\}$ \\
\hline & $(0.97)$ & $(0.05)$ & $(0.97)$ & $(0.00)$ \\
\hline \multirow[t]{2}{*}{ Ln $S P$} & $1.485[1]$ & $-6.370[0]$ & $1.698\{1\}$ & $-6.294\{3\}$ \\
\hline & $(0.97)$ & $(0.00)$ & $(0.98)$ & $(0.00)$ \\
\hline \multirow[t]{2}{*}{ Ln $E R$} & $-1.745[1]$ & $-6.710[0]$ & $-1.678\{3\}$ & $-6.710\{0\}$ \\
\hline & $(0.72)$ & $(0.00)$ & $(0.75)$ & $(0.00)$ \\
\hline \multirow[t]{2}{*}{$T B 91$} & $-3.485[0]$ & & $-3.683\{4\}$ & \\
\hline & $(0.05)$ & 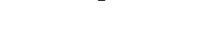 & $(0.03)$ & 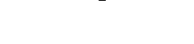 \\
\hline \multirow[t]{2}{*}{$\operatorname{Ln} Y$} & $0.615[0]$ & $-9.089[0]$ & $0.712\{4\}$ & $-9.147\{4\}$ \\
\hline & $(0.99)$ & $(0.00)$ & $(0.99)$ & $(0.00)$ \\
\hline \multirow[t]{2}{*}{ Ln M3 } & $-0.599[4]$ & $-3.729[3]$ & $-1.438\{80\}$ & $-11.019\{13\}$ \\
\hline & $(0.86)$ & $(0.01)$ & $(0.56)$ & $(0.00)$ \\
\hline \multirow[t]{2}{*}{$G-\operatorname{Sec} 10$} & $-1.992[0]$ & & $-1.992\{0\}$ & \\
\hline & $(0.05)$ & & $(0.05)$ & 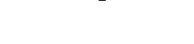 \\
\hline \multirow[t]{2}{*}{ Fin Dev } & $-1.521[4]$ & $-2.707[3]$ & $-0.911\{8\}$ & $-11.447\{2\}$ \\
\hline & $(0.52)$ & $(0.08)$ & $(0.95)$ & $(0.00)$ \\
\hline
\end{tabular}

Notes. Values in parenthesis are probability value

Source: Authors' Calculation

\section{B. Cointegration results}

The presence of long-run relationships in Equation (2) is tested using bound test (Table 4). The ARDL model is selected based on the AIC criterion by automatically choosing the optimal lag length. Table 4 shows the estimation of Model 1 (i.e., M1) and Model 2 (i.e., M3). As argued by Pesaran and Pesaran (1997), the study introduces the normalization method by considering each variable under study as a response variable in the ARDL approach.

The long-run relationships exist among variables for Model $1 \mid$ (A) and (C) when the regressions are normalized on $M 1$ and $r$, respectively. The calculated F-statistic under Model 1 for $\mathrm{F}_{\mathrm{A}}=3.733$ and $\mathrm{F}_{\mathrm{C}}=5.046$ are greater than the upper critical bound value at $10 \%$ and $1 \%$ level of significance, respectively. Meanwhile, the rest of the dependent variables under Model 1 are insignificant due to the lesser F-value than the lower critical bound. Similarly, cointegration is established in Model $2 \mid(\mathrm{A})$ and $(\mathrm{F})$, when the regressions are normalized on M3 and FD, respectively. The F-statistic under Model 2 for $F_{A}=3.407$ and $F_{F}=3.764$ are higher than the upper critical bound at a $10 \%$ significance level. 
Table 4. Bounds Test for Co-integration Relationship

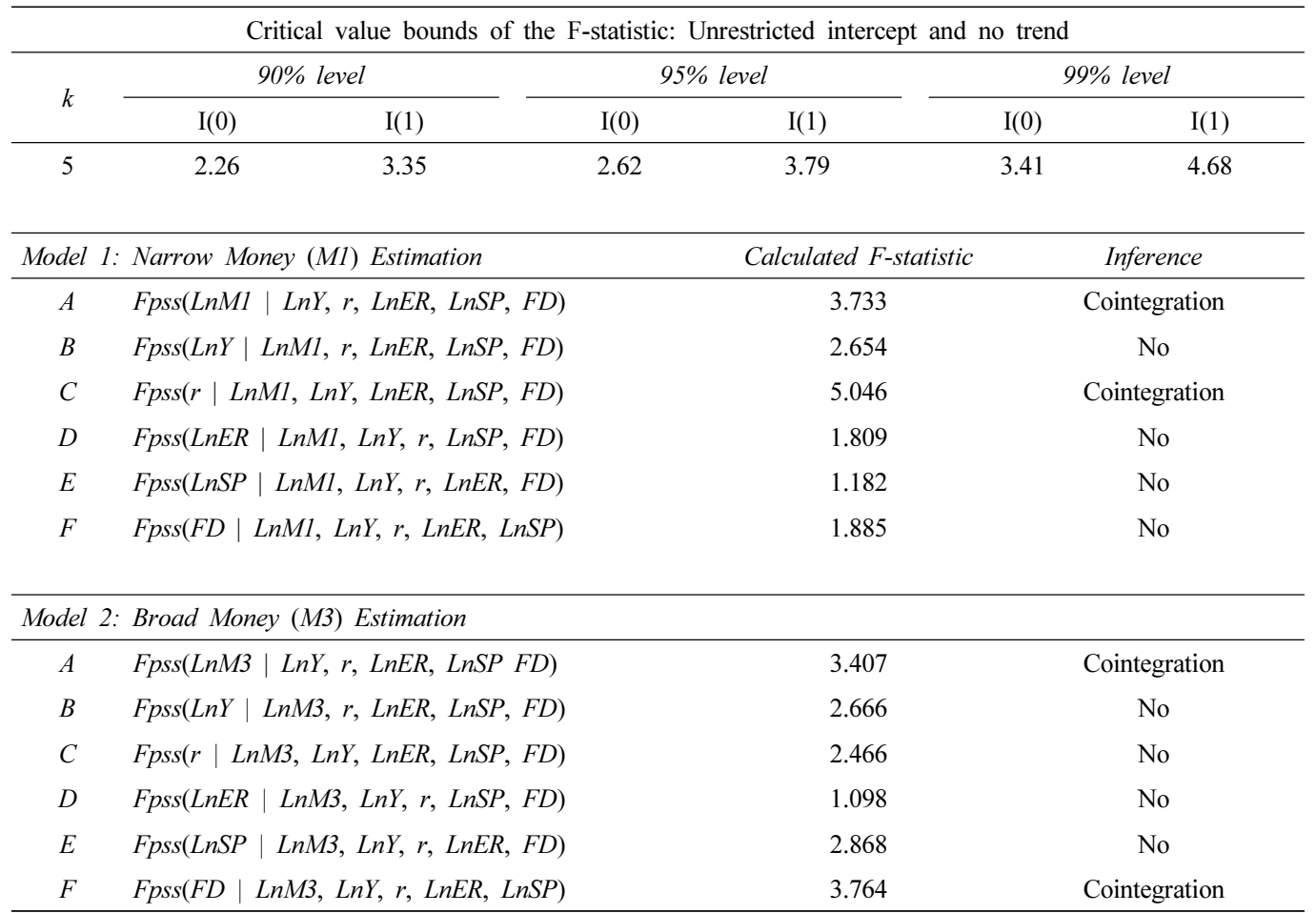

Source: Authors' Calculation

Having determined a cointegration among variables, the study looks at the short-and long-run impacts of the explanatory variables on M1 (i.e., Model 1|(A)) and M3 (i.e., Model 2|(A)). In particular, we are interested in checking the stability and short- and long-run behavior of M3 because the FD, which is the main concern of the current study, is more intact to the components of M3 rather than M1. Table 5 reporst the long-run contemporaneous relationship. In M1, the coefficient of income level and interest rate is significant at a $1 \%$ significance level, and signs are also as per economic theory. However, the rest of the variables are insignificant. Conversely, in M3, all coefficients of its covariates are significant at 5\%, and the signs are also as per economic theory. Therefore, M3 behaves well in India compared to M1, which is supported by a recent study (see Adil et al., 2020a). Focusing on FD, the coefficients for M1 and M3 models are positive, but significant only for M3. There is a theoretical rationale behind positive relationships. As in many emerging economies, the demand for M1 and M3 is expected to increase due to monetization increase (or departure from the barter system of trade) of the economy, which is possible due to FD. In India, the positive sign of FD elasticity of M3 is justified because, after the 1990s economic reform, the Indian economy is dragged toward more monetization, which is attributed to spur in economic growth, causing a higher transaction of M3 in daily life (Adil et al., 2020a). Thus, the need for highly liquid transaction 
balances is accompanied by the higher monetization process. In short, a decrease in the velocity of real money balances is considered an indicator of FD, which implies a decline of the barter economy and, in turn, the rise of commercial banking (Bordo and Jonung, 2003).

Importantly, the long-run coefficient of $\operatorname{LnY}$ in model M1 is greater than 1 in magnitude. Several suggestions are proposed; for instance, money acts as a store of value, and its demand may increase more than proportionately to an increase in income level (Hossain, 2012). Similarly, the $>1$ income elasticity is plausible because real money balances may fulfill both the need for transaction and investment, especially when money demand for transaction and investment purposes is blurred during the deregulated financial environment (Corker and Tseng, 1991). Thus, in the late 1970s and early 1980 s, FD and economic reform of the 1990s in India might have caused $>1$ income elasticity of real money balances.

Table 5. Estimated Long-run Coefficients for M1 and M3 Models

\begin{tabular}{ccccccc}
\hline \multirow{2}{*}{ ARDL } & \multicolumn{7}{c}{ Variables } \\
\cline { 2 - 7 } & Ln $Y$ & $r$ & LnER & LnSP & FD & Constant \\
\hline \multirow{2}{*}{ Model 1 $\mid(A)$} & 1.051 & -0.022 & 0.100 & 0.063 & 0.000 & -5.707 \\
& $(0.00)$ & $(0.00)$ & $(0.60)$ & $(0.35)$ & $(0.95)$ & $(0.00)$ \\
\hline \multirow{2}{*}{ Model 2|(A) } & 0.668 & -0.029 & 0.457 & 0.160 & 0.009 & -3.386 \\
& $(0.01)$ & $(0.00)$ & $(0.00)$ & $(0.04)$ & $(0.01)$ & $(0.00)$ \\
\hline
\end{tabular}

Notes. Selected Model 1 | (A): ARDL(1, 0, 1, 0, 0, 1) and Selected Model 2। (A): $\operatorname{ARDL}(1,3,4,1,4,0)$; values in parenthesis are probability values.

Source: Authors' Calculation

Table 6 presents the results of short-run coefficients estimated within the ARDL framework and its associated series of diagnostic tests. The short-run results are consistent with the long-run results in economic theory. All variables are significant except for the exchange rate and SP in M1. Meanwhile, in M3, the variables are also significant, except income level and exchange rate. The ECT for M1 and M3 are correctly signed (i.e., negative) and statistically significant at a 1\% significance level. The coefficient of ECT reflects the speed of adjustment of real money balances to long-run equilibrium due to changes in their covariates. Following a deviation from the long run in the previous period, convergence to the steady-state is corrected by the magnitude of $31.7 \%$ and $32.9 \%$ per quarter for M1 and M3, respectively.

Lastly, the present study conducts some diagnostic tests to ensure the validity of the estimated parameters in the ARDL and unrestricted ECM framework. The series of diagnostic tests are important because the short-run dynamics remain essential in testing for the stability of long-run coefficients in the model (Hossain, 2012, quoted from Pesaran and Pesaran, 1997). The estimated models show compatibility with the dataset while passing all diagnostic tests. Moreover, the reported diagnostic results in Table 6 show the absence of serial correlation, heteroscedastic 
error, model misspecification, and non-normality of the residuals for both M1 and M3. The parameter stability tests are conducted using the CUSUM and CUSUMQ tests. Figures 2 and 3 are plotted for M1, whereas Figures 4 and 5 are plotted for M3, for the robustness of the respective ECM. These figures do not depict systematic or haphazard changes in the regression coefficients because recursive residuals are within the $5 \%$ critical bounds of the parameter stability. Thus, the quarterly ECM of M1 and M3 has stable parameters.

Table 6. Error Correction Representation for the Selected ARDL Models

\begin{tabular}{|c|c|c|}
\hline Variable & Model $1 \mid(A)$ & Model $2 \mid(A)$ \\
\hline$\triangle L n M I$ & - & - \\
\hline$\triangle \operatorname{Ln} M 3$ & - & - \\
\hline$\triangle \operatorname{Ln} Y$ & $0.333(0.00)$ & $0.113 \quad(0.49)$ \\
\hline$\Delta r$ & $-0.012 \quad(0.00)$ & $-0.010 \quad(0.00)$ \\
\hline$\triangle L n E R$ & $0.032 \quad(0.59)$ & $-0.015 \quad(0.85)$ \\
\hline$\triangle L n S P$ & $0.020 \quad(0.35)$ & $-0.064 \quad(0.00)$ \\
\hline$\triangle F D$ & $0.025 \quad(0.00)$ & $0.010 \quad(0.00)$ \\
\hline \multirow[t]{2}{*}{$E C T t-1$} & $-0.317 \quad(0.00)$ & $-0.329 \quad(0.00)$ \\
\hline & \multicolumn{2}{|c|}{ Diagnostic statistic } \\
\hline Adjusted $R$ & 0.997 & 0.999 \\
\hline$D W$-stat & 1.951 & 2.086 \\
\hline$\chi^{2} B G-L M$ & $1.057 \quad(0.59)$ & $1.918 \quad(0.38)$ \\
\hline$\chi^{2}$ RESET & $1.064 \quad(0.31)$ & $0.230 \quad(0.63)$ \\
\hline$\chi^{2}$ Norm & $0.598 \quad(0.74)$ & $3.167 \quad(0.21)$ \\
\hline$\chi^{2} B P G$ & $9.176 \quad(0.33)$ & $14.669 \quad(0.68)$ \\
\hline
\end{tabular}

Notes. Selected Model $1 \mid$ (A): ARDL(1, 0, 1, 0, 0, 1) and Selected Model 2 |(A): ARDL(1, 3, 4, 1, 4, 0); values in parenthesis are probability values.

Source: Authors' Calculation

Figure 2. CUSUM for M1-Model 1|(A)

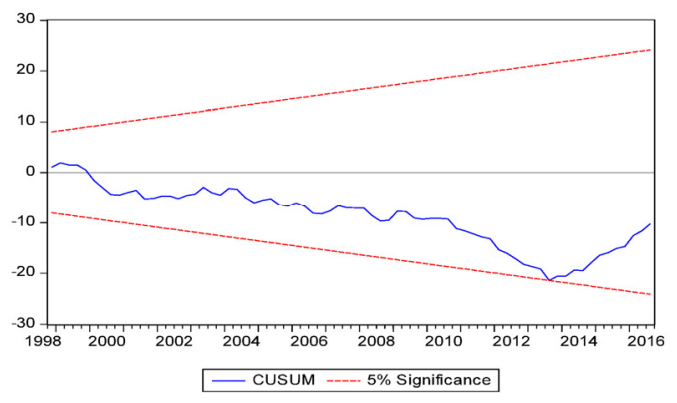

Source: Authors' Calculation
Figure 3. CUSUMQ for M1-Model $1 \mid(\mathrm{A})$

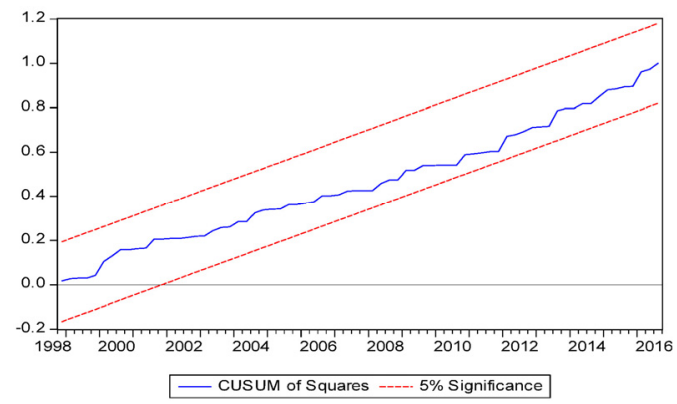

Source: Authors' Calculation 
Figure 4. CUSUM for M3-Model 2|(A)

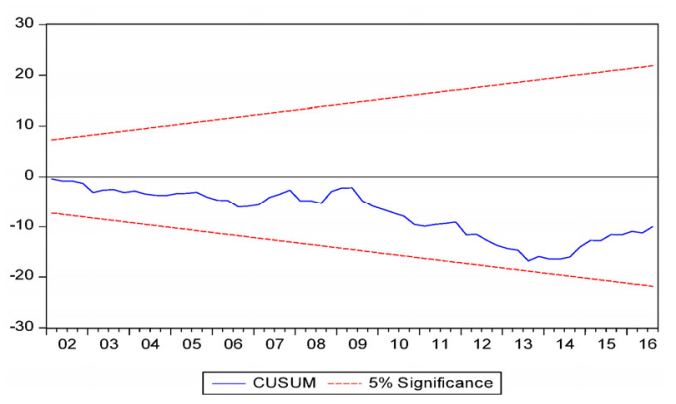

Source: Authors' Calculation
Figure 5. CUSUMQ for M3-Model 2|(A)

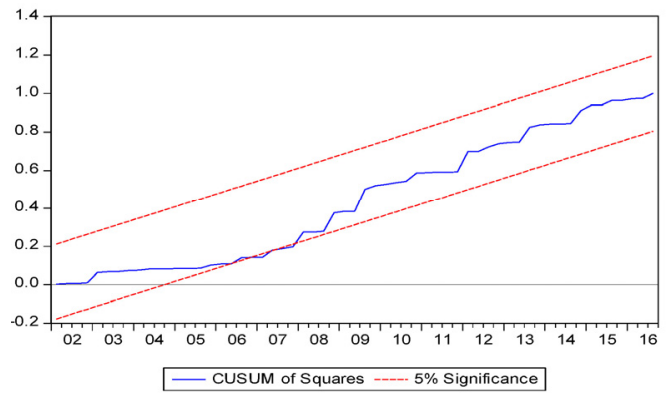

Source: Authors' Calculation

\section{Analysis of granger causality results}

A cointegrating relationship among Fpss(LnM1 | LnY, r, LnER, LnSP, FD), and Fpss(LnM3 | $L n Y, r, \operatorname{LnER}, \operatorname{LnSP} F D$ ) reflects a possible Granger causality at least one way. The cointegration implies the existence of causal relation, but it does not reflect the direction of temporal causality among variables. The short- and long-run Granger causality is examined within the VECM framework. Tables 7 and 8 for M1 and M3, respectively, show the Granger causality analysis (see Appendix). In Table 7, the coefficient of explanatory variables (with the help of their respective $p$-values) in each of the six equations indicates the statistical significance of short-run causal effects. In the equation considering M1 a dependent variable, no causal effects are observed because none of the explanatory variables is significant. Focusing on long-run causal effects, the p-value of the coefficient of ECT indicates the statistical significance of the long-run causal effects. The coefficient of the lagged ECT is significant, with the expected sign at a $10 \%$ significance level. Thus, it reenforces the long-run cointegrating relationship. In the long run, the covariates Granger-cause M1, implying that causality runs interactively through the ECT from its covariates to M1. Likewise, the causal effects for M3 in Table 8 can be interpreted.

\section{Impulse response functions and variance decompositions' results}

The alternative way to obtain information regarding relationships is to look for generalized IRF. In Figure 6, the first row and first column plot the generalized impulse response of M1 to shocks in $L n Y, r, L n E R, L n S P$, and $F D$ (see Figures 6 and 7 in the Appendix). A shock in $L n Y$ and $L n S P$ has a positive and increasing effect on $L n M 1$ over ten quarters. Meanwhile, a shock to $F D$ has a positive effect on $L n M 1$ throughout the period, declining up to the fourth quarter and then stagnating until the end. Conversely, a shock in the LnER and $r$ negatively affects LnM1. The responses in LnMI attributed to shock in its covariates are well inclined with economic theory and coefficient estimates with the ARDL model. Likewise, the response in the M3 model to shocks 
in its covariates can be analyzed in Figure 7.

The detection of Granger causality is restricted to within-sample tests, which are helpful to know; in the sample period, the possible Granger exogeneity or endogeneity of the response variable is determined. However, the Granger-causality test cannot infer the degree of exogeneity of the variables beyond the sample period. To this end, the study employs the VD. Table 9 presents the VD result for M1 over ten quarters (see Tables 9 and 10 in the Appendix). Consistent with the results of cointegration and VECM Granger-causality tests, the VD depicts that LnY, FD, LnM1, and LnER are the most exogenous variables. A high proportion of their shocks is explained by their own innovations compared to the contributions of own shocks to innovations for $r$ and LnSP. In the 10th quarters, forecast error variances for $L n Y, L n M 1, L n E R$, and $F D$ are explained by their own innovations, which are $87 \%, 81 \%, 75 \%$, and $66 \%$, respectively. Furthermore, in the 10 th quarter, very little of the forecast error in $L n M 1$ is explained by $L n E R, r$, and $L n Y$. Likewise, the percentage of forecast error variance for the M3 model can be examined in Table 10.

\section{Summary and Concluding Remarks}

The stable money demand relationship has had been a cornerstone of monetary policy. The empirical research on this issue is inevitable because it reflects the existence of a predictable link between real money balances and their covariates, which helps investigate the impact of the monetary sector on the real sector. However, after the emergence of FD in the 1970s and early 1980s, MDF became unstable. Thereafter, policymakers became reluctant to monitor the growth rate of money supply. In turn, the role of MDF became questionable in monetary policy formulation. Moreover, the interest rate targeting has started under the new monetary policy strategy-that is, inflation-targeting. Woodford (2000) aptly argued that even if the demand for base money is eliminated, monetary policy should continue to be effective. Consequently, monetary aggregates do not contain much information to conduct monetary policy. Later on, this has led to the notion that money is inconsequential in maintaining price stability under inflation-targeting.

Despite paying less attention to money demand in policy formulation, the monetarists continue to be uncomfortable with the decreasing role of money and the increasing the role of interest rate in monetary policy under an inflation-targeting framework (Barnet, 1997; King, 2001; Thornton, 2014). In this regard, Taylor (2009) noted that even though less emphasis has given on stable MDF under the inflation-targeting framework, the latest global financial crisis of 2007 has rekindled the interest in excess liquidity in explaining inflation and boom-bust cycles. The rate of inflation is intensely linked with the growth rate of money supply in long-run; therefore, the role of money cannot be subsided from monetary policy, even though the MDF is not sufficiently predictable to have central importance in monetary policy formulation. Therefore, increment in the growth rate of the money supply should 
be taken seriously, at least as an important information on a potential increase in inflation rate.

Accordingly, this study investigates the impact of FD on the short-and long-run relationships and stability of MDF in the context of India. We estimate real narrow (M1) and broad (M3) money after taking FD into account during the post-reform era from 1996:Q2 to 2016:Q3. The application of ARDL, CUSUM, CUSUMQ, and Granger-causality test based on VECM, IRFs, and VDs confirmed a well-defined stable short- and long-run money demand specification in India. In particular, the broad money's (M3) coefficient estimates are more robust and accommodates the new economic policy changes well. One plausible explanation is that the components of M3 are capturing well the recent FD in India. After having stable MDF, policymaker and central bankers can use monetary aggregates as an indicator or information variable to predict output gaps and inflationary expectations under the inflation-targeting framework. In a nutshell, the Reserve Bank of India (i.e., the central bank of India) may focus on real M3 as an indicator or information variable to achieve its ultimate macroeconomic goals, that is, flexible inflation-targeting.

The aforementioned policy implication is inclined with the monetary policy strategy of the European Central Bank (ECB), where the ECB has adopted the two-pillar strategy: "monetary analysis" and "economic analysis." Under the monetary analysis, the price stability is a major concern. Moreover, the Governing Council of the ECB frequently notices the advancement in monetary aggregates in the so-called Quarterly Monthly Assessment in the Euro system's monetary policy strategy (Fischer et al., 2009; Pospíšil, 2017). Thus, the ECB examines the change in monetary aggregates under its second pillar besides other economic indicators.

\section{References}

Adam, C. S. (1991). Financial innovation and the demand forf M3 in the UK 1975-86. Oxford Bulletin of Economics and Statistics, 53(4), 401-424.

Adil, M. H., Hatekar, N., \& Sahoo, P. (2020a). The impact of financial innovation on the money demand function: An empirical verification in India. Margin: The Journal of Applied Economic Research, 14(1), 28-61.

Adil, M. H., Haider, S., \& Hatekar, N. R. (2020b). Empirical assessment of money demand stability under India's open economy: Non-linear ARDL approach. Journal of Quantitative Economics, 18(4), 891-909.

Adil, M. H., Haider, S., \& Hatekar, N. R. (2020c). Revisiting money demand stability in India: Some post-reform evidence (1996-2016). Indian Economic Journal, 66(3/4), 326-346.

Aggarwal, S. (2016). Determinants of money demand for India in presence of structural break: An empirical analysis. Business and Economic Horizons, 12(4), 173-177.

Arrau, P., \& De Gregorio, J. D. (1993). Financial innovation and money demand: Application to Chile and Mexico. Review of Economics and Statistics, 75(3), 524-530. 
Arrau, P., De Gregorio, J., Reinhart, C. M., \& Wickham, P. (1995). The demand for money in developing countries: Assessing the role of financial innovation. Journal of Development Economics, 46(2), 317-340.

Baba, Y., Hendry, D. F., \& Starr, R. M. (1992). The demand for M1 in the USA, 1960-1988. Review of Economic Studies, 59(1), 25-61.

Bahmani-Oskooee, M., \& Rhee, H. J. (1994). Long-run elasticities of the demand for money in Korea: Evidence from cointegration analysis. International Economic Journal, 8(2), 83-93.

Bahmani-Oskooee, M., \& Shabsigh, G. (1996). The demand for money in Japan: Evidence from cointegration analysis. Japan and the World Economy, 8(1), 1-10.

Bahmani-Oskooee, M. (2001). How stable is M2 money demand function in Japan? Japan and the World Economy, 13(4), 455-461.

Bahmani-Oskooee, M., \& Ng, R. C. W. (2002). Long-run demand for money in Hong Kong: An application of the ARDL model. International Journal of Business and Economics, 1(2), 147.

Bahmani-Oskooee, M., \& Rehman, H. (2005). Stability of the money demand function in Asian developing countries. Applied Economics, 37(7), 773-792.

Bahmani-Oskooee, M., \& Wang, Y. (2007). How stable is the demand for money in China? Journal of Economic Development, 32(1), 21-34.

Bahmani-Oskooee, M., Bahmani, S., Kones, A., \& Kutan, A. M. (2015). Policy uncertainty and the demand for money in the United Kingdom. Applied Economics, 47(11), 1151-1157.

Bahmani-Oskooee, M., \& Bahmani, S. (2015). Nonlinear ARDL approach and the demand for money in Iran. Economics Bulletin, 35(1), 381-391.

Bahmani-Oskooee, M., \& Baek, J. (2017). Economic uncertainty, monetary uncertainty and the Korean demand for money. Journal of Economic Policy Reform, 20(1), 86-97.

Ball, L. (2012). Short-run money demand. Journal of Monetary Economics, 59(7), 622-633.

Barnett, W. A. (1997). Which road leads to stable money demand? Economic Journal, 107(443), 1171-1185.

Bordo, M., D., \& Jonung, L. (2003). Demand for money: An analysis of the long-run behavior of the velocity of circulation. New Brunswick and London: Transaction Publishing.

Brown, R. L., Durbin, J., \& Evans, J. M. (1975). Techniques for testing the constancy of regression relationships over time. Journal of the Royal Statistical Society: Series B, 37(2), 149-163.

Christiano, L., Motto, R., \& Rostagno, M. (2007). Two reasons why money and credit may be useful in monetary policy (No. w13502). National Bureau of Economic Research.

Corker, R. J., \& Tseng, W. S. (1991). Financial liberalization, money demand, and monetary policy in Asian countries (No. 84). International Monetary Fund.

Dickey, D. A., \& Fuller, W. A. (1981). Likelihood ratio statistics for autoregressive time series with a unit root. Econometrica, 49(4), 1057-1072.

Darrat, A. F. (1986). The demand for money in some major OPEC members: Regression estimates and stability results. Applied Economics, 18(2), 127-142.

Dekle, R., \& Pradhan, M. (1999). Financial liberalization and money demand in the ASEAN countries. International Journal of Finance and Economics, 4(3), 205-215.

Friedman, M. (1956). The quantity theory of money: A restatement. Studies in the Quantity Theory of Money, 5, 3-31. 
Funke, N., \& Thornton, J. (1999). The demand for money in Italy, 1861-1988. Applied Economics Letters, 6(5), 299-301.

Friedman, B. (2003). The LM curve: A not-so-fond farewell (No. w10123). National Bureau of Economic Research.

Fischer, B., Lenza, M., Pill, H., \& Reichlin, L. (2009). Monetary analysis and monetary policy in the euro area 1999-2006. Journal of International Money and Finance, 28(7), 1138-1164.

Goldfeld, S. M., Fand, D. I., \& Brainard, W. C. (1976). The case of the missing money. Brookings Papers on Economic Activity, 1976(3), 683-739.

Goldfeld, S. M. (1989). Demand for money: Empirical studies. In Money (pp. 131-143). London: Palgrave Macmillan.

Gurley, J. G., \& Shaw, E. S. (1955). Financial aspects of economic development. American Economic Review, 45(4), 515-538.

Hafer, R. W., \& Kutan, A. M. (1994). Economic reforms and long-run money demand in China: Implications for monetary policy. Southern Economic Journal, 60(4), 936-945.

Haider, S., Ganaie, A. A., \& Kamaiah, B. (2017). Asymmetric exchange rate effect on money demand under open economy in case of India. Economics Bulletin, 37(1), 168-179.

Hassan, M. K., Sanchez, B., \& Yu, J. S. (2011). Financial development and economic growth in the organization of Islamic conference countries. Journal of King Abdulaziz University - Islamic Economics, 362(3068), 1-56.

Hossain, A. A. (2012). Modelling of narrow money demand in Australia: An ARDL cointegration approach, 1970-2009. Empirical Economics, 42(3), 767-790.

Hoffman, D. L., \& Rasche, R. H. (1989). Long-run income and interest elasticities of money demand in the United States. Working Paper, No. 2949. National Bureau of Economic Research.

James, G. A. (2005). Money demand and financial liberalization in Indonesia. Journal of Asian Economics, 16(5), 817-829.

King, M. (2001). No money, no inflation The role of money in the economy. Économie Internationale, 4(4), 111-131.

Kumar, S., \& Webber, D. J. (2013). Australasian money demand stability: Application of structural break tests. Applied Economics, 45(8), 1011-1025.

Laidler, D. E. (1982). Monetarist perspectives. Harvard University Press.

Laidler, D. E. (1969). The definition of money: Theoretical and empirical problems. Journal of Money, Credit, and Banking, 1(3), 508-525.

Laidler, D. E. (1993). The demand of money: Theories, evidence and the problems. New York: Harper Collins.

Lewis, M. K., \& Mizen, P. D. (2000). Monetary economics. OUP catalogue.

McNown, R., \& Wallace, M. S. (1992). Cointegration tests of a long-run relation between money demand and the effective exchange rate. Journal of International Money and Finance, 11(1), 107-114.

Melnick, R. (1990). The demand for money in Argentina 1978-1987: Before and after the Austral program. Journal of Business and Economic Statistics, 8(4), 427-434.

Miller, S. M. (1991). Monetary dynamics: An application of cointegration and error-correction modeling. 
Journal of Money, Credit, and Banking, 23(2), 139-154.

Mundell, R. A. (1963). Capital mobility and stabilization policy under fixed and flexible exchange rates. Canadian Journal of Economics and Political Science/Revue canadienne d'Economique et de Science politique, 29(4), 475-485.

Mwanzia, J. K., Ndanshau, M. O., \& Luvanda, E. (2017). The effect of stock prices on demand for money: The case of Kenya. Tanzania Economic Review, 5(1-2).

Narayan, P. K., \& Smyth, R. (2004). Temporal causality and the dynamics of exports, human capital and real income in China. International Journal of Applied Economics, 1(1), 24-45.

Nelson, E. (2003). The future of monetary aggregates in monetary policy analysis. Journal of Monetary Economics, 50(5), 1029-1059.

Nelson, C. R., \& Plosser, C. R. (1982). Trends and random walks in macroeconomic time series: Some evidence and implications. Journal of Monetary Economics, 10(2), 139-162.

Payne, J. E. (2003). Post stabilization estimates of money demand in Croatia: Error correction model using the bounds testing approach. Applied Economics, 35(16), 1723-1727.

Pospísil, R. (2017). The monetary aggregates and current objectives of European Central Bank. Studia Prawno-Ekonomiczne, 105, 341-363.

Phillips, P. C. B., \& Perron, P. (1988). Testing for a unit root in time series regression. Biometrika, 75(2), 335-346.

Pesaran, M. H., Shin, Y., \& Smith, R. J. (2001). Bounds testing approaches to the analysis of level relationships. Journal of Applied Econometrics, 16(3), 289-326.

Pesaran, M. H., \& Pesaran, B. (1997). Working with Microfit 4.0: Interactive econometric analysis. Oxford University Press.

Romer, D. H. (2000). Keynesian macroeconomics without the LM curve. Journal of Economic Perspectives, 14(2), 149-170.

Ramachandran, M. (2004). Do broad money, output, and prices stand for a stable relationship in India? Journal of Policy Modeling, 26(8/9), 983-1001.

Singh, P., \& Pandey, M. K. (2009). Structural break, stability and demand for money in India. MPRA Paper, No. 15425. Retrieved from https://mpra.ub.uni-muenchen.de/15425/

Siklos, P. L. (1993). Income velocity and institutional change: Some new time series evidence, 1870-1986. Journal of Money, Credit, and Banking, 25(3), 377-392.

Svensson, L. E. (2008). What have economists learned about monetary policy over the past 50 years, January. Retrieved from http://arseosvensson.se/files/papers/Buba\%20709.pdf

Sims, C. A. (1980). Macroeconomics and reality. Econometrica, 48(1), 1-48.

Taylor, J. B. (2009). The financial crisis and the policy responses: An empirical analysis of what went wrong (No. w14631). National Bureau of Economic Research.

Thornton, D. L. (2014). Monetary policy: Why money matters (and interest rates don't). Journal of Macroeconomics, 40, 202-213.

Woodford, M. (2000). Monetary policy in a world without money. International Finance, 3(2), 229-260. 
116 Journal of Economic Integration Vol. 37, No. 1

\section{Appendix}

Table 7. Results of Granger Causality for M1: Model 1 | (A)

\begin{tabular}{|c|c|c|c|c|c|c|c|}
\hline \multirow{2}{*}{$\begin{array}{c}\text { Dependent } \\
\text { Variable }\end{array}$} & \multicolumn{6}{|c|}{ Short-run } & \multirow{2}{*}{$\begin{array}{c}\text { Long-run } \\
E C T_{t-1}\end{array}$} \\
\hline & $\triangle L n M l$ & $\Delta \operatorname{Ln} Y$ & $\Delta r$ & $\triangle L n E R$ & $\triangle \operatorname{Ln} S P$ & $\triangle F D$ & \\
\hline \multirow[t]{2}{*}{$\triangle L n M 1$} & -0.067 & 0.042 & 0.005 & 0.148 & 0.010 & -0.005 & -0.176 \\
\hline & $(0.69)$ & $(0.91)$ & $(0.35)$ & $(0.43)$ & $(0.85)$ & $(0.43)$ & $(0.06)$ \\
\hline \multirow[t]{2}{*}{$\triangle \operatorname{Ln} Y$} & -0.031 & -0.047 & -0.003 & -0.051 & 0.016 & 0.002 & -0.020 \\
\hline & $(0.58)$ & $(0.70)$ & $(0.13)$ & $(0.41)$ & $(0.37)$ & $(0.28)$ & $(0.52)$ \\
\hline \multirow[t]{2}{*}{$\Delta r$} & -4.491 & 5.043 & -0.071 & 0.309 & -1.182 & 0.246 & -8.429 \\
\hline & $(0.20)$ & $(0.51)$ & $(0.49)$ & $(0.94)$ & $(0.29)$ & $(0.05)$ & $(0.00)$ \\
\hline \multirow[t]{2}{*}{$\triangle L n E R$} & -0.178 & -0.318 & 0.003 & 0.133 & -0.036 & 0.004 & 0.001 \\
\hline & $(0.12)$ & $(0.21)$ & $(0.43)$ & $(0.30)$ & $(0.33)$ & $(0.34)$ & $(0.99)$ \\
\hline \multirow[t]{2}{*}{$\triangle \operatorname{Ln} S P$} & 0.590 & 2.162 & -0.013 & 0.150 & 0.287 & -0.027 & 0.380 \\
\hline & $(0.16)$ & $(0.02)$ & $(0.30)$ & $(0.74)$ & $(0.03)$ & $(0.06)$ & $(0.10)$ \\
\hline \multirow[t]{2}{*}{$\triangle F D$} & -6.290 & 5.108 & 0.116 & 5.139 & 1.233 & -0.050 & -2.538 \\
\hline & $(0.19)$ & $(0.63)$ & $(0.41)$ & $(0.33)$ & $(0.42)$ & $(0.77)$ & $(0.34)$ \\
\hline
\end{tabular}

Notes. Values in parenthesis are probability value.

Source: Authors' calculation

Table 8. Results of Granger Causality for M3: Model 2 | (A)

\begin{tabular}{|c|c|c|c|c|c|c|c|}
\hline \multirow{2}{*}{$\begin{array}{c}\text { Dependent } \\
\text { Variable }\end{array}$} & \multicolumn{6}{|c|}{ Short-run } & \multirow{2}{*}{$\begin{array}{c}\text { Long-run } \\
E C T_{t-1}\end{array}$} \\
\hline & $\triangle \operatorname{Ln} M 3$ & $\triangle \operatorname{Ln} Y$ & $\Delta r$ & $\triangle L n E R$ & $\triangle L n S P$ & $\triangle F D$ & \\
\hline \multirow[t]{2}{*}{$\triangle L n M 3$} & -0.122 & -0.010 & -0.009 & 0.135 & -0.004 & -0.004 & -0.008 \\
\hline & $(0.41)$ & $(0.96)$ & $(0.11)$ & $(0.20)$ & $(0.90)$ & $(0.17)$ & $(0.22)$ \\
\hline \multirow[t]{2}{*}{$\triangle \operatorname{Ln} Y$} & -0.028 & -0.087 & 0.000 & -0.053 & 0.012 & 0.001 & -0.003 \\
\hline & $(0.76)$ & $(0.47)$ & $(0.88)$ & $(0.39)$ & $(0.50)$ & $(0.68)$ & $(0.45)$ \\
\hline \multirow[t]{2}{*}{$\Delta r$} & -2.545 & 6.972 & 0.005 & 1.211 & -0.820 & -0.002 & -0.435 \\
\hline & $(0.42)$ & $(0.10)$ & $(0.97)$ & (0.59) & $(0.21)$ & $(0.97)$ & $(0.00)$ \\
\hline \multirow[t]{2}{*}{$\triangle L n E R$} & -0.381 & -0.329 & -0.007 & 0.169 & -0.038 & 0.005 & 0.000 \\
\hline & $(0.04)$ & $(0.17)$ & $(0.30)$ & $(0.19)$ & $(0.31)$ & $(0.18)$ & $(0.97)$ \\
\hline \multirow[t]{2}{*}{$\triangle \operatorname{Ln} S P$} & 1.257 & 2.058 & 0.021 & -0.085 & 0.323 & -0.019 & 0.062 \\
\hline & $(0.05)$ & $(0.02)$ & $(0.38)$ & $(0.85)$ & $(0.02)$ & $(0.13)$ & $(0.03)$ \\
\hline \multirow[t]{2}{*}{$\triangle F D$} & -10.943 & 4.991 & -0.385 & 8.745 & 0.293 & -0.145 & -0.972 \\
\hline & $(0.12)$ & $(0.60)$ & $(0.14)$ & $(0.08)$ & $(0.84)$ & $(0.29)$ & $(0.00)$ \\
\hline
\end{tabular}

Notes. Values in parenthesis are probability value.

Source: Authors' calculation 
Table 9. Decomposition of Variance for M1: Model 1 | (A)

(percentage of forecast variance explained by innovations)

\begin{tabular}{|c|c|c|c|c|c|c|c|}
\hline \multicolumn{8}{|c|}{ Variance Decomposition of LnM1 } \\
\hline Period & S.E. & Ln $M 1$ & $\operatorname{Ln} Y$ & $F D$ & $r$ & Ln ER & Ln SP \\
\hline 1 & 0.04 & 100.00 & 0.00 & 0.00 & 0.00 & 0.00 & 0.00 \\
\hline 5 & 0.08 & 87.46 & 1.75 & 5.06 & 1.40 & 0.18 & 4.15 \\
\hline 10 & 0.11 & 81.28 & 2.70 & 7.81 & 2.04 & 0.09 & 6.08 \\
\hline \multicolumn{8}{|c|}{ Variance Decomposition of $\operatorname{Ln} Y$} \\
\hline Period & S.E. & Ln $M 1$ & $\operatorname{Ln} Y$ & $F D$ & $r$ & Ln ER & Ln SP \\
\hline 1 & 0.01 & 3.44 & 96.56 & 0.00 & 0.00 & 0.00 & 0.00 \\
\hline 5 & 0.03 & 6.75 & 88.12 & 0.13 & 1.07 & 2.21 & 1.72 \\
\hline 10 & 0.05 & 7.98 & 87.03 & 0.09 & 0.84 & 2.38 & 1.68 \\
\hline \multicolumn{8}{|c|}{ Variance Decomposition of FD } \\
\hline Period & S.E. & Ln M1 & $\operatorname{Ln} Y$ & $F D$ & $r$ & Ln ER & Ln SP \\
\hline 1 & 1.20 & 45.18 & 0.06 & 54.77 & 0.00 & 0.00 & 0.00 \\
\hline 5 & 2.28 & 29.10 & 1.50 & 66.15 & 0.05 & 0.22 & 2.99 \\
\hline 10 & 3.16 & 27.54 & 1.91 & 66.67 & 0.03 & 0.18 & 3.67 \\
\hline \multicolumn{8}{|c|}{ Variance Decomposition of $r$} \\
\hline Period & S.E. & Ln M1 & $\operatorname{Ln} Y$ & $F D$ & $r$ & Ln ER & Ln SP \\
\hline 1 & 0.88 & 5.95 & 1.89 & 13.08 & 79.09 & 0.00 & 0.00 \\
\hline 5 & 1.82 & 29.51 & 13.96 & 10.75 & 36.41 & 0.98 & 8.38 \\
\hline 10 & 2.53 & 30.39 & 20.02 & 6.52 & 27.75 & 1.89 & 13.43 \\
\hline \multicolumn{8}{|c|}{ Variance Decomposition of Ln ER } \\
\hline Period & S.E. & Ln $M 1$ & $\operatorname{Ln} Y$ & $F D$ & $r$ & Ln ER & Ln SP \\
\hline 1 & 0.03 & 2.02 & 1.58 & 0.67 & 0.30 & 95.42 & 0.00 \\
\hline 5 & 0.09 & 9.20 & 6.72 & 5.20 & 0.72 & 77.08 & 1.08 \\
\hline 10 & 0.13 & 10.42 & 7.22 & 5.78 & 0.67 & 74.74 & 1.17 \\
\hline \multicolumn{8}{|c|}{ Variance Decomposition of Ln SP } \\
\hline Period & S.E. & Ln $M 1$ & $\operatorname{Ln} Y$ & $F D$ & $r$ & Ln ER & Ln SP \\
\hline 1 & 0.10 & 1.09 & 9.76 & 1.36 & 1.94 & 16.13 & 69.72 \\
\hline 5 & 0.31 & 10.70 & 18.96 & 5.37 & 3.13 & 11.79 & 50.05 \\
\hline 10 & 0.43 & 12.86 & 19.18 & 4.73 & 4.26 & 11.33 & 47.65 \\
\hline
\end{tabular}

Source: Authors' calculation 
Table 10. Decomposition of Variance for M3: Model 2 |(A)

(percentage of forecast variance explained by innovations)

\begin{tabular}{|c|c|c|c|c|c|c|c|}
\hline \multicolumn{8}{|c|}{ Variance Decomposition of LnM3 } \\
\hline Period & S.E. & Ln $M 3$ & $\operatorname{Ln} Y$ & $F D$ & $r$ & $\operatorname{Ln} S P$ & Ln $E R$ \\
\hline 1 & 0.02 & 100.00 & 0.00 & 0.00 & 0.00 & 0.00 & 0.00 \\
\hline 5 & 0.05 & 92.92 & 0.61 & 2.24 & 2.59 & 0.01 & 1.64 \\
\hline 10 & 0.07 & 92.27 & 0.84 & 2.30 & 2.79 & 0.04 & 1.77 \\
\hline \multicolumn{8}{|c|}{ Variance Decomposition of $\operatorname{Ln} Y$} \\
\hline Period & S.E. & Ln $M 3$ & $\operatorname{Ln} Y$ & $F D$ & $r$ & Ln $S P$ & Ln $E R$ \\
\hline 1 & 0.01 & 0.01 & 99.99 & 0.00 & 0.00 & 0.00 & 0.00 \\
\hline 5 & 0.03 & 0.04 & 94.09 & 0.05 & 0.10 & 5.14 & 0.58 \\
\hline 10 & 0.05 & 0.07 & 92.13 & 0.04 & 0.15 & 6.95 & 0.66 \\
\hline \multicolumn{8}{|c|}{ Variance Decomposition of FD } \\
\hline Period & S.E. & Ln M3 & $\operatorname{Ln} Y$ & $F D$ & $r$ & Ln $S P$ & Ln ER \\
\hline 1 & 1.13 & 31.01 & 0.35 & 68.65 & 0.00 & 0.00 & 0.00 \\
\hline 5 & 2.33 & 19.23 & 2.70 & 60.43 & 2.93 & 10.52 & 4.19 \\
\hline 10 & 3.40 & 17.98 & 5.30 & 51.16 & 2.56 & 18.76 & 4.24 \\
\hline \multicolumn{8}{|c|}{ Variance Decomposition of $r$} \\
\hline Period & S.E. & Ln M3 & $\operatorname{Ln} Y$ & $F D$ & $r$ & Ln $S P$ & Ln ER \\
\hline 1 & 0.51 & 9.15 & 0.66 & 1.62 & 88.57 & 0.00 & 0.00 \\
\hline 5 & 1.18 & 13.71 & 7.07 & 0.80 & 67.82 & 9.79 & 0.80 \\
\hline 10 & 1.85 & 9.57 & 12.44 & 0.34 & 54.25 & 22.65 & 0.75 \\
\hline \multicolumn{8}{|c|}{ Variance Decomposition of Ln SP } \\
\hline Period & S.E. & Ln M3 & $\operatorname{Ln} Y$ & $F D$ & $r$ & Ln $S P$ & Ln ER \\
\hline 1 & 0.10 & 0.47 & 12.71 & 0.51 & 2.93 & 83.38 & 0.00 \\
\hline 5 & 0.28 & 0.31 & 31.56 & 0.26 & 9.60 & 57.74 & 0.52 \\
\hline 10 & 0.37 & 0.22 & 34.60 & 0.16 & 13.01 & 51.10 & 0.91 \\
\hline \multicolumn{8}{|c|}{ Variance Decomposition of Ln ER } \\
\hline Period & S.E. & Ln M3 & $\operatorname{Ln} Y$ & $F D$ & $r$ & Ln $S P$ & Ln ER \\
\hline 1 & 0.03 & 0.10 & 2.86 & 0.02 & 0.06 & 18.95 & 78.01 \\
\hline 5 & 0.09 & 2.36 & 10.99 & 1.33 & 0.79 & 23.98 & 60.55 \\
\hline 10 & 0.13 & 2.64 & 11.97 & 1.55 & 0.94 & 23.82 & 59.08 \\
\hline
\end{tabular}

Source: Authors' calculation 
Figure 6. Impulse response function for model $1 \mid$ (A)-M1-MDF

Response of LNNM1WPI to Generalized One S.D. Innovations

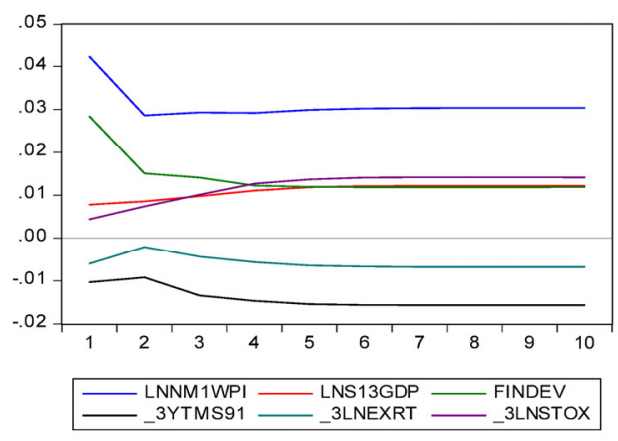

Response of FINDEV to Generalized One S.D. Innovations

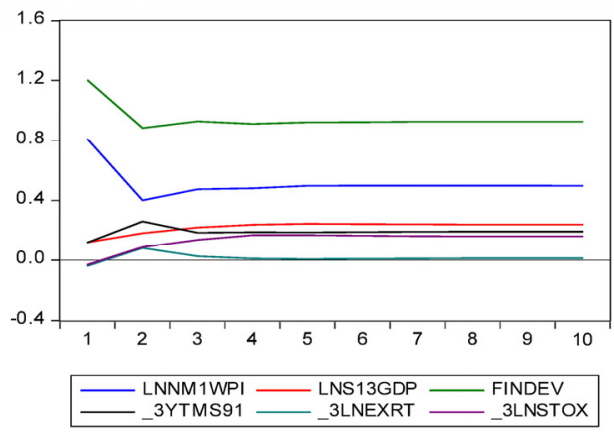

Response of _3LNEXRT to Generalized One S.D. Innovations

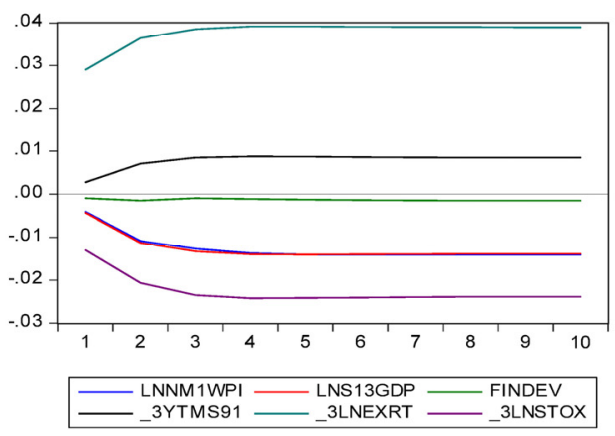

Response of LNS13GDP to Generalized One S.D. Innovations

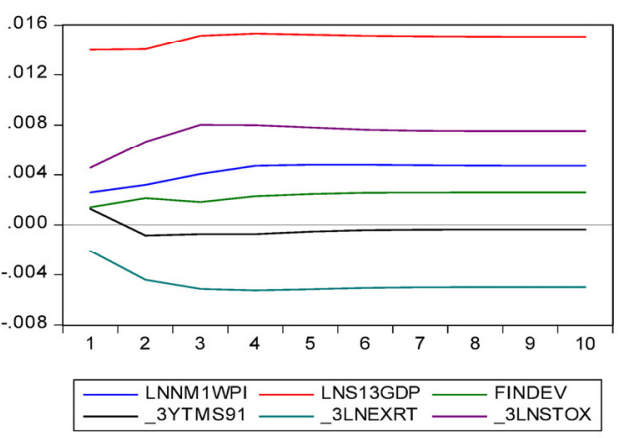

Response of 3YTMS91 to Generalized One S.D. Innovations

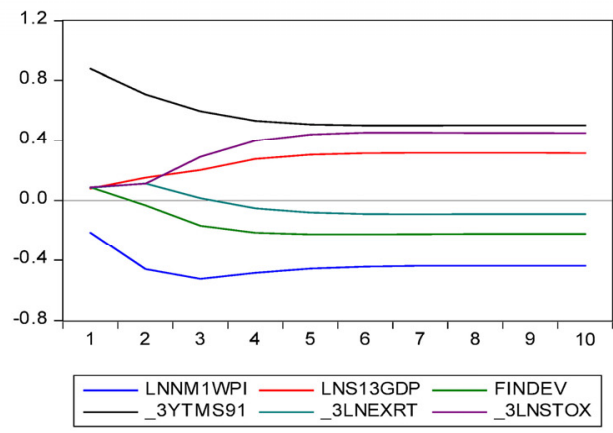

Response of _3LNSTOX to Generalized One S.D. Innovations

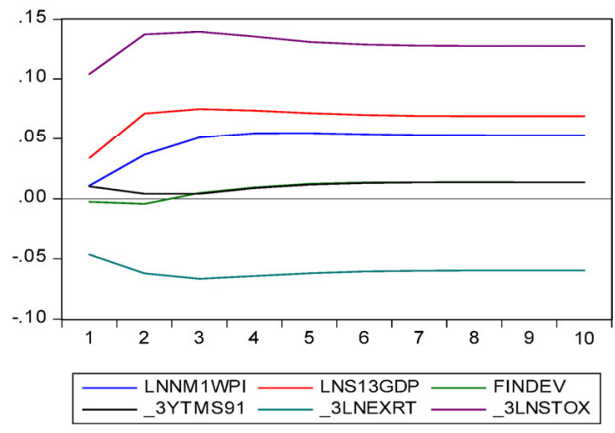

Source: Authors' calculation 
Figure 7. Impulse Response Function for Model $2 \mid$ (A)-M3-MDF

Response of LNBM3WPI to Generalized One S.D. Innovations

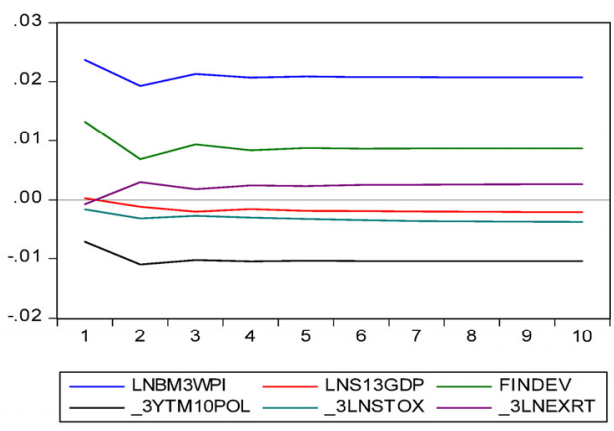

Response of FINDEV to Generalized One S.D. Innovations

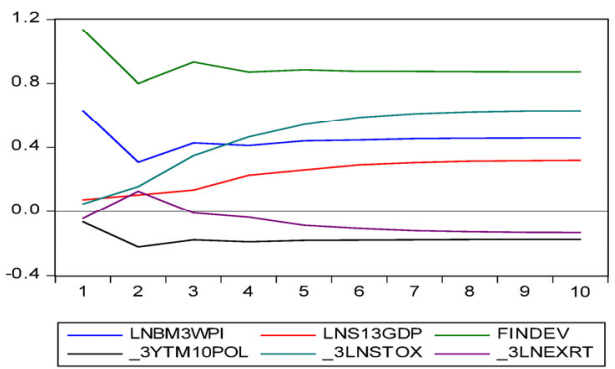

Response of _3LNSTOX to Generalized One S.D. Innovations

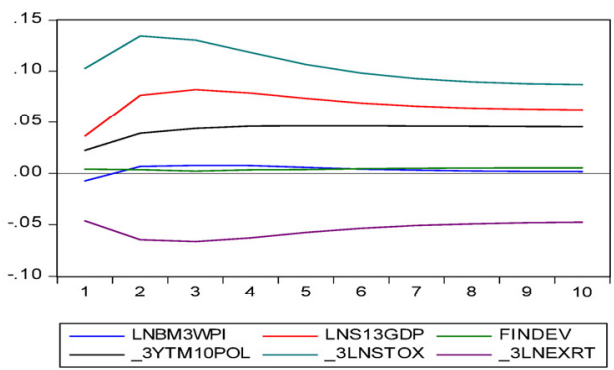

Response of LNS13GDP to Generalized One S.D. Innovations

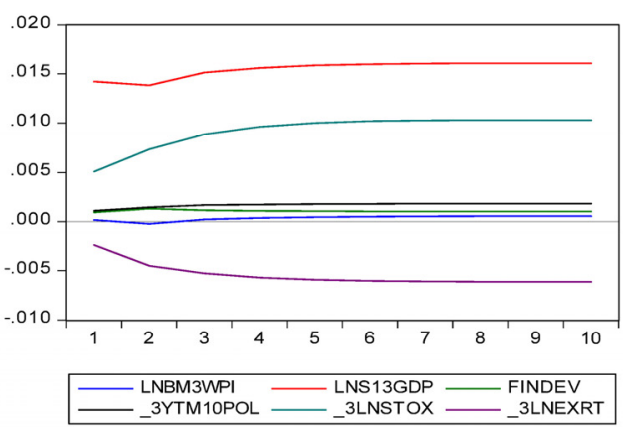

Response of 3YTM10POL to Generalized One S.D. Innovations

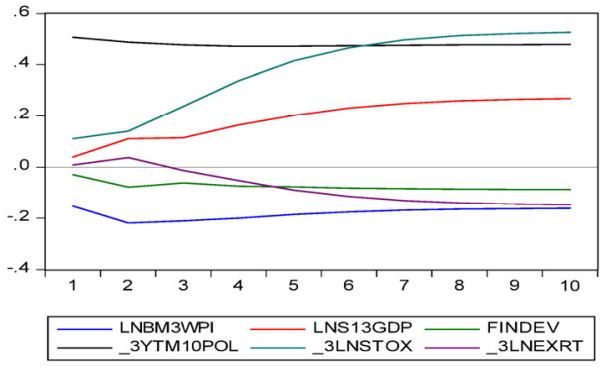

Response of _3LNEXRT to Generalized One S.D. Innovations

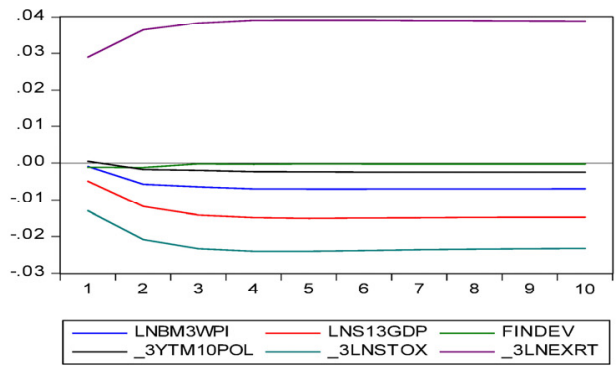

Source: Authors' calculation 